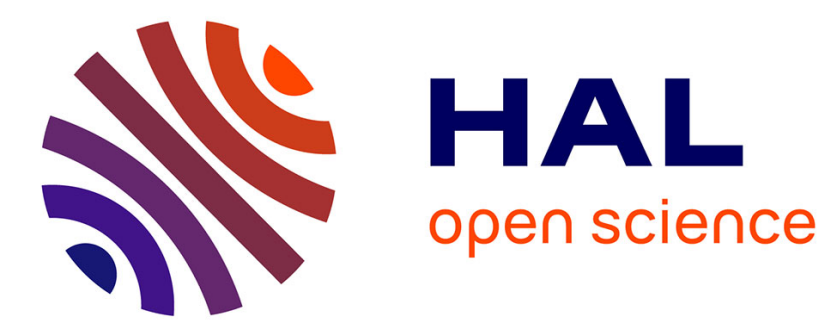

\title{
PLA-poloxamer/poloxamine copolymers for ligament tissue engineering: sound macromolecular design for degradable scaffolds and MSC differentiation
}

Adrien Leroy, Benjamin Nottelet, Claire Bony, Coline Pinese, Benoît Charlot, Xavier Garric, Danièle Noël, Jean Coudane

\section{To cite this version:}

Adrien Leroy, Benjamin Nottelet, Claire Bony, Coline Pinese, Benoît Charlot, et al.. PLApoloxamer/poloxamine copolymers for ligament tissue engineering: sound macromolecular design for degradable scaffolds and MSC differentiation. Biomaterials Science, 2015, 3 (4), pp.617-626. 10.1039/c4bm00433g . hal-01369239

\section{HAL Id: hal-01369239 \\ https://hal.science/hal-01369239}

Submitted on 25 Aug 2021

HAL is a multi-disciplinary open access archive for the deposit and dissemination of scientific research documents, whether they are published or not. The documents may come from teaching and research institutions in France or abroad, or from public or private research centers.
L'archive ouverte pluridisciplinaire HAL, est destinée au dépôt et à la diffusion de documents scientifiques de niveau recherche, publiés ou non, émanant des établissements d'enseignement et de recherche français ou étrangers, des laboratoires publics ou privés. 
PLA-Poloxamer/Poloxamine Copolymers for Ligament Tissue Engineering: Sound Macromolecular Design for Degradable Scaffolds and MSCs Differentiation

Adrien Leroy, Benjamin Nottelet *,Claire Bony, Coline Pinese, Benoît Charlot, Xavier Garric, Danièle Noël *, Jean Coudane

Dr A. Leroy, Dr B. Nottelet, Dr C. Pinese, Prof. X. Garric, Prof. J. Coudane

Institut des Biomolécules Max Mousseron (IBMM), UMR CNRS 5247

University of Montpellier 1, University of Montpellier 2, ENSCM

Faculty of Pharmacy, 15 Av. C. Flahault,

F-34093 Montpellier, France.

C. Bony, Dr D. Noël

INSERM U844

Hôpital Saint-Eloi, 80 Av. Augustin Fliche

F-34295 Montpellier, France

Dr B. Charlot

Institut d'Electronique du Sud (IES), UMR CNRS 5412

University of Montpellier 2, Place E. Bataillon

F-34095 Montpellier Cedex 5, France

* Corresponding authors

Tel.: +33 411759697

e-mail addresses: benjamin.nottelet@univ-montp1.fr,daniele.noel@inserm.fr 


\begin{abstract}
The treatment of anterior cruciate ligament (ACL) failures remains a current clinical challenge. The present study aims at providing suitable degradable scaffolds for ligament tissue engineering. First, we focus on the design and the evaluation of poly(lactide)/poloxamer or poly(lactide)/poloxamine multiblock copolymers selected and developed to have suitable degradation and mechanical properties to match ACL repair. In a second part it is shown that the copolymers can be processed in the form of microfibers and scaffolds consisting in a combination of twisted/braided fibers to further modulate the mechanical properties and prepare scaffold prototypes suitable for ligament application. Finally, after assessment of their cytocompatibility, the polymer scaffolds are associated to mesenchymal stem cells (MSCs). MSCs differentiation toward a ligament fibroblast phenotype is promoted by a dual stimulation including an inductive culture medium and cyclic mechanical loads. RT-qPCR analyses confirm the potential of our scaffolds and MSCs for ACL regeneration with upregulation of some differentiation markers including Scleraxis, Tenascin-C and Tenomodulin.
\end{abstract}

\title{
Keywords
}

Tissue engineering, ligament, poly(lactide) copolymers, twisted-braided scaffolds, mesenchymal stem cells 


\section{Introduction}

The anterior cruciate ligament (ACL) is known to have a poor healing capacity. Combination of various factors including low cellularity, low vascularity and the absence of blood clot at the site of injury to stabilize the two ligament ends and help tissue growth are often considered as the key mechanisms behind its failure to heal. ${ }^{[1]}$ Therefore, after injury, these soft tissues are currently repaired thanks to surgical procedures. Concerning ACL reconstruction, the risk of disease transmission, the lack of donors and the growing number of injuries requiring surgery (around 175,000 each year in the U.S.) promoted the development of autograft techniques based on the use of hamstring or patellar tendons. ${ }^{[2]}$ Despite the proven success of these autograft treatments, they are still facing with limitations and disadvantages like additional risks linked to the harvesting of the transplant, long recovery time (between 6 and 12 months), high surgery costs, limited availability of autologous tissues in case of recurrent injuries and donor site morbidity which may induce residual pain, weakness and other complications. ${ }^{[2,3]}$

For all these reasons, the conception of alternative synthetic grafts attracted a growing attention in the last decades. Following the detected failures of definitive synthetic grafts which were widely implanted in the 1980s and early 1990s, ${ }^{[4]}$ advances in cell biology and in the field of biodegradable materials led researchers to develop ligament substitutes through tissue engineering. In particular the strategy consisting in the association of a bioresorbable scaffold with cells in order to finally regenerate the tissues has been widely applied in the case of ACL tissue engineering. For the design of the scaffold, studies have been led on many kinds of materials including biological scaffolds (obtained from dermis, small intestine submucosa or pericardium ${ }^{[5]}$ and natural polymers like silk, ${ }^{[6,7]}$ collagen $^{[8]}$ and polysaccharides (chitosan, cellulose). ${ }^{[9,}{ }^{10]}$ The main limitations of these materials come from the difficulty to finely control their mechanical and degradation properties. These properties are indeed extremely important since the scaffold needs to mimic the ligament's behavior to efficiently replace it. Scaffold has to take over the ligament during the regeneration 
without presenting too high initial mechanical properties that may induce a stress shielding phenomenon and ultimately lead to the formation of weak tissues. It should also be degradable to be fully replaced by neo-tissues at the end of tissue repair process. To meet these requirements, attention has been paid to synthetic degradable polymers and especially to aliphatic polyesters like polylactide (PLA), ${ }^{[11,12,13]}$ polyglycolide $(\mathrm{PGA}),{ }^{[14]}$ poly $\left(\varepsilon\right.$-caprolactone) $(\mathrm{PCL}),{ }^{[10,12,15]}$ and their copolymers. ${ }^{[7,16,17]}$ Associating such polymers with a textile processing allows to obtain a wide range of properties and to modulate the mechanical properties to fit the ligament specific mechanical profile of ligaments (Supporting Information Figure S1). However, it remains difficult to design a scaffold which meets the required specifications of degradation and mechanical properties. In that regard, many studies on ACL tissue engineering focus on the processing rather than on the materials chemistry. On the opposite, our group being involved in the synthesis of original degradable aliphatic polyesters and especially of polylactide-polyethylene glycol (PLAPEG) block copolymers for many years, ${ }^{[18]}$ we were interested in the preparation of PLA copolymers showing high biocompatibility and able to approach the ACL mechanical properties while featuring appropriate degradation rates for tissue engineering of ligament. For that purpose we recently synthesized PLA-poloxamer and PLA-poloxamine copolymers whose mechanical properties and degradation profiles may show promises for ligament tissue engineering. ${ }^{[19]}$ It is to note that examples of PLA-poloxamers can be found in literature. However, these polymers are designed for hydrogels and drug delivery applications, ie. with macromolecular parameters (hydrophilicity, low molecular weight, low to no crystallinity) that are far from the ones targeted for ligament repair. ${ }^{[20]}$

Finally, a last point to consider is that ligament tissue engineering does not only requires good materials and sound scaffolds architectures but also cells allowing cellular proliferation and differentiation towards ligament forming cells. For that purpose the use of mesenchymal stromal or stem cells (MSCs) as cell source for the regeneration of ACL tissues is a common choice. Contrary 
to ACL fibroblasts, MSCs can easily be isolated from adult bone marrow or fat tissue and they exhibit a high potential of proliferation and differentiation, which makes them of particular interest as a suitable source for autologous transplant. ${ }^{[2,21,22]}$ MSCs nevertheless require stimulation steps to differentiate toward a ligament fibroblast phenotype. Several strategies are currently used to induce this differentiation, including the use of growth factors. ${ }^{[2,22]}$ For instance, epidermal growth factor (EGF), fibroblast growth factor (FGF), growth differentiation factor (GDF), insulin-like growth factor (IGF), platelet-derived growth factor (PDGF) or transforming growth factor- $\beta$ (TGF- $\beta$ ) are known to induce cell proliferation, synthesis of extracellular matrix (ECM) proteins and, to some extent, orientation toward a fibroblastic phenotype. ${ }^{[23,24]}$ However, despite the number of studies on this subject, there is still no standard procedure to specifically induce the differentiation toward ligament fibroblast. Another popular strategy is the application of mechanical stimulation to scaffolds seeded with MSCs, which will activate cell surface receptors and downstream intracellular signaling cascades to promote ECM production. ${ }^{[25]}$ This technique gained popularity thanks to the development of bioreactors designed to mimic physiological conditions and to provide complex multidimensional strains (tension, torsion). ${ }^{[13,17,22,26]}$

The main objective of the present work is therefore to propose original degradable copolymers that will meet the demanding requirements of ligament tissue engineering scaffolds with respect to i) mechanical properties, ii) degradation rate and iii) MSCs differentiation. In a first part original PLA/Pluronic and PLA/Tetronic copolymers are synthesized. Their properties and their processing to microfibers and structured scaffolds by twisting and braiding procedures are assessed. In a second part MSCs' proliferation and differentiation on the obtained scaffolds are evaluated under dual stimulation with i) inductive culture medium containing ascorbic acid and $\beta$-glycerophosphate that are known to promote cell proliferation, ECM production and differentiation, ${ }^{[27]}$ and ii) mechanical stimulation through cyclic loadings. 


\section{Results and discussion}

\subsection{Syntheses}

In an attempt to provide an alternative to current degradable ligament tissue engineering scaffolds that have poor mechanical properties (natural polymers, amorphous PLA), or too low degradation rates (PCL, crystalline PLA), we synthesized multiblock copolymers made of PLA and Pluronic or Tetronic by ROP (Figure 1). As described in our previous study, this strategy leads to a family of copolymers with a good control of the macromolecular parameters (molecular weight, linear vs. star block copolymers, crystallinity). This control allows one to find a best match between the copolymer candidate and the applications requirements. For example, such polymers have already been described in literature, but to the best of our knowledge, with oligoesters segments, ie. compositions and molecular parameters that were chosen to meet the requirements of hydrogels and drug delivery applications. ${ }^{[20]}$ On the opposite, here we take advantage of the approach to meet mechanical and degradation properties suitable for ligament repair and to modulate and improve the biomaterial properties compared to the classically used PLA homopolymers.

Based on our past results, two copolymers were selected for ligament scaffolds development as they showed good mechanical and degradation properties in preliminary short terms evaluations (7 weeks), while being highly compatible with L929 fibroblasts culture. ${ }^{[19]}$ More in details, the targeted copolymers had high molecular weights of $200 \mathrm{~kg} / \mathrm{mol}$ and were composed of crystalline PLA $_{94}$ side blocks (94\% L-lactic units, 6\% D-lactic units) associated with either Pluronic (94P200) or Tetronic (94T200) central blocks. Molecular weights of the copolymers were determined by ${ }^{1} \mathrm{H}$ NMR spectroscopy, thanks to Equations 1 to 3, and were in good agreement with the targeted values. Molecular weights obtained from SEC analyses were $c a$. twice lower than the ones calculated from ${ }^{1} \mathrm{H}$ NMR spectra. This is in agreement with the literature where PLA analyses under the chosen SEC conditions classically give values about two times lower than theoretical ones. ${ }^{[28]}$ Full details on the copolymers compositions and molecular weights are provided in Supporting Information Table S1. 


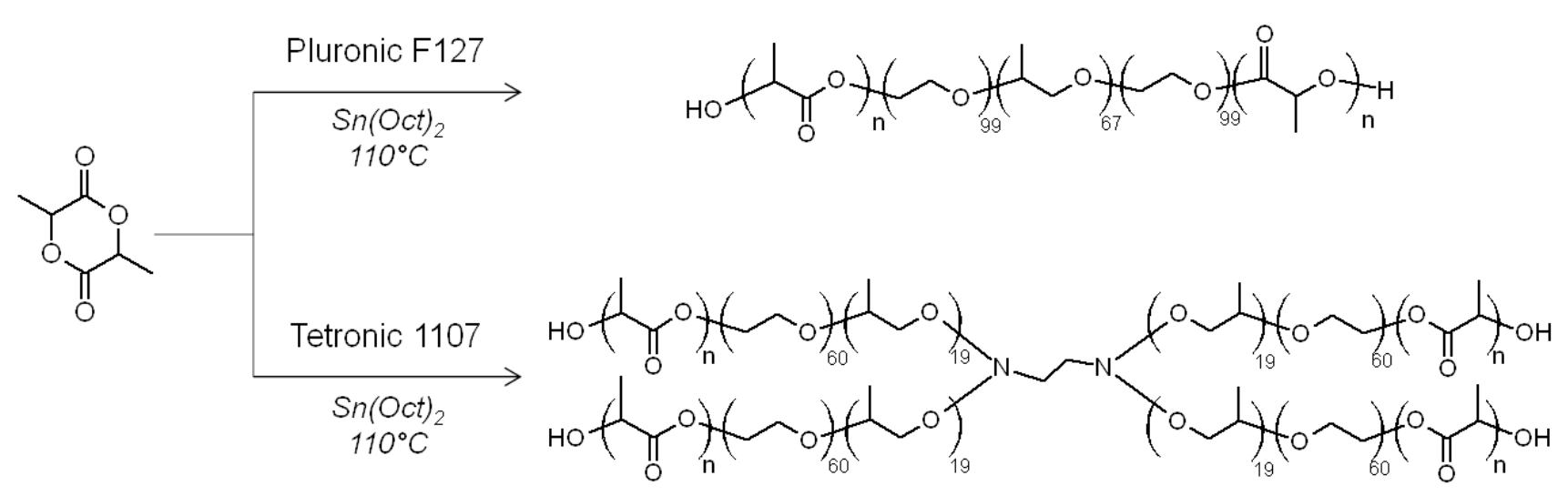

Figure 1. General synthesis scheme of 94P200 and 94T200 copolymers

Before scaffold processing, tensile tests were preliminary carried out on copolymer films (Table 1). Under this form, the mechanical properties were not the one of native ACL but still in a suitable range, which would allow a closer fit with ACL properties thanks to the scaffold processing step. To further characterize the selected copolymers, their long term degradation behaviors in vitro were assessed on films in PBS (pH 7.4) at $37^{\circ} \mathrm{C}$ and over a 6 month period. As shown in Figure 2 the absence of degradation for PLA94 homopolymer $(\mathrm{Mn}=200000 \mathrm{~g} / \mathrm{mol})$ that may ultimately lead to weaker regenerated tissues was confirmed after six months with only $15 \%$ molecular weight loss. In opposition, the copolymers 94P200 and 94T200 with their hydrophilic central block showed steady molecular weight decrease over the same period of time with ca. $30 \%$ after one month and $80 \%$ after six months. This intermediate degradation rate should be of advantage to avoid the wellknown stress shielding effect compared to crystalline PLA homopolymers which are classically used despite a very slow degradation rate and high mechanical properties compared to ACL (Supporting Information Figure S2). 
Table 1. Mechanical properties of copolymers before processing and after processing compared to ACL mechanical properties. $\left(\mathrm{E}=\right.$ Young's modulus, $\sigma_{\mathrm{f}}=$ stress at failure, $\varepsilon_{\mathrm{f}}=$ strain at failure, $\sigma_{\mathrm{y}}=$ yield stress, $\varepsilon_{\mathrm{y}}=$ yield strain)

\begin{tabular}{lllllll}
\hline \multirow{2}{*}{ Copolymer } & E & $\sigma_{\mathrm{y}}$ & $\varepsilon_{\mathrm{y}}$ & $\sigma_{\mathrm{f}}$ & $\varepsilon_{\mathrm{f}}$ \\
& & $(\mathrm{MPa})$ & $(\mathrm{MPa})$ & $(\%)$ & $(\mathrm{MPa})$ & $(\%)$ \\
\hline \multirow{2}{*}{$94 \mathrm{P} 200$} & film & $556 \pm 50$ & $11 \pm 1$ & $2.8 \pm 0.5$ & $18 \pm 2$ & $613 \pm 37$ \\
& fiber & $2181 \pm 165$ & $29 \pm 3$ & $1.3 \pm 0.2$ & $33 \pm 1$ & $11 \pm 5$ \\
& scaffold & $346 \pm 109$ & $19 \pm 3$ & $6.4 \pm 0.7$ & $24 \pm 3$ & $78 \pm 23$ \\
\hline \multirow{2}{*}{$94 \mathrm{~T} 200$} & film & $455 \pm 24$ & $14 \pm 1$ & $3.5 \pm 0.3$ & $20 \pm 1$ & $765 \pm 55$ \\
& fiber & $2299 \pm 31$ & $16 \pm 1$ & $0.7 \pm 0.0$ & $22 \pm 6$ & $10 \pm 5$ \\
\hline \multirow{2}{*}{ ACL $^{[29]}$} & & $49-163$ & $/$ & $5.4 \pm 2.0$ & $29 \pm 1$ & $20 \pm 2$ \\
\hline
\end{tabular}

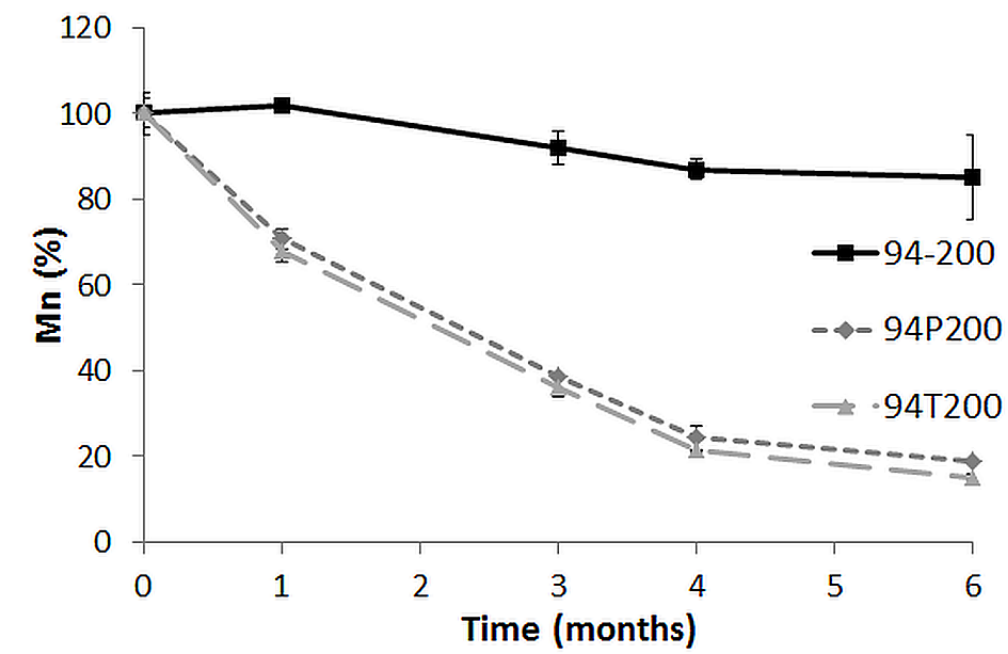

Figure 2. Molecular weight evolution during in vitro degradation (PBS, $\mathrm{pH} 7.4,37^{\circ} \mathrm{C}$ ) of $94 \mathrm{P} 200$ and 94T200 copolymers compared to PLA homopolymer (94-200)

\subsection{Fibers properties}

With the aim of developing scaffolds for ligament regeneration, both 94P200 and 94T200 copolymers were extruded to obtain microfibers. Average fiber diameter was calculated from the analysis of optic microscopy pictures with 5 fibers randomly selected from each picture. Fibers 
were obtained with average diameters of $162 \pm 20 \mu \mathrm{m}$ for $94 \mathrm{P} 200$ copolymer and $193 \pm 18 \mu \mathrm{m}$ for 94T200 copolymer. As degradable polymers like PLA are sensitive to thermal degradation, copolymers properties were characterized by SEC and DSC before and after extrusion. Results are summarized in Table 2. The residence in the extrusion chamber induced a significant degradation of the copolymers with $\mathrm{ca} 40 \%$ molecular weight decrease and dispersity increasing from 2.0 to 2.5 for $94 \mathrm{P} 200$ and from 1.7 to 2.3 for $94 \mathrm{~T} 200$. Despite the maintenance of copolymers under nitrogen flow during the process, these results indicated a beginning of thermal degradation by chain scissions that was already described in the literature. ${ }^{[30]}$ Moreover, even though no significant change was observed in glass and melting temperatures, an important increase of the enthalpy of melting could be noticed for both 94P200 and 94T200 copolymers. This higher crystallinity can be explained both by the shortening of the polymer chains which promotes crystallization and by the chains stretching which occurs during the drawing step.

Table 2. Comparison of copolymers molecular weights and thermal properties before and after extrusion

\begin{tabular}{|c|c|c|c|c|c|c|}
\hline \multicolumn{2}{|c|}{ Copolymer } & $\begin{array}{l}\overline{\boldsymbol{M n}} \\
\text { decrease }\end{array}$ & $Đ$ & $\begin{array}{l}\mathrm{T}_{\mathrm{g}} \\
\left({ }^{\circ} \mathrm{C}\right)\end{array}$ & $\begin{array}{l}\mathrm{T}_{\mathrm{m}} \\
\left({ }^{\circ} \mathrm{C}\right)\end{array}$ & $\begin{array}{l}\Delta \mathrm{H}_{\mathrm{m}} \\
(\mathrm{J} / \mathrm{g})\end{array}$ \\
\hline \multirow{2}{*}{ 94P200 } & before extrusion & \multirow{2}{*}{$42 \%$} & 2.0 & 48 & 150 & 6.8 \\
\hline & after extrusion & & 2.5 & 46 & 152 & 14.4 \\
\hline \multirow{2}{*}{$94 \mathrm{~T} 200$} & before extrusion & \multirow{2}{*}{$43 \%$} & 1.7 & 46 & 150 & 3.6 \\
\hline & after extrusion & & 2.3 & 46 & 152 & 23.6 \\
\hline
\end{tabular}

Tensile mechanical tests were carried out to evaluate the consequences of extrusion on mechanical properties. Results are summarized in Table 1 and compared to mechanical properties of copolymer films obtained by compression molding. ${ }^{[19]}$ Extrusion caused major changes of the mechanical properties with strong increases of Young's moduli and characteristic stresses $\left(E, \sigma_{y}\right.$ and $\left.\sigma_{f}\right)$ whereas characteristic strains $\left(\varepsilon_{y}\right.$ and $\left.\varepsilon_{f}\right)$ strongly decreased after the process. These changes were expected 
as a result of the drawing step, which occasioned chains stretching during the extrusion process and led to more crystalline copolymers as shown by the increase of melting enthalpies (Table 2).

\subsection{Scaffolds mechanical properties}

In a next step, and with aim to yield mechanical properties closer to ACL, copolymer fibers were used to produce scaffolds (Figure 3) following a twisting-braiding procedure reported to yield structures of interest for ligament repair. ${ }^{[31]}$ Tensile mechanical tests were carried out on these scaffolds. A clear evolution of the scaffolds mechanical profile was observed compared to that of fibers (Figure 4a). While the fibers' stress-strain curve presented a linear region (elastic region ruled by Hooke's law of elasticity) followed by a decrease in the slope (irreversible plastic deformation and damage region), the scaffold's one first showed a low-stress zone followed by the linear and the damage regions. The twisting-braiding processing therefore leads to scaffolds with mechanical profiles similar to the typical three-stage ligament stress-strain curve (toe region, linear region and yield region).

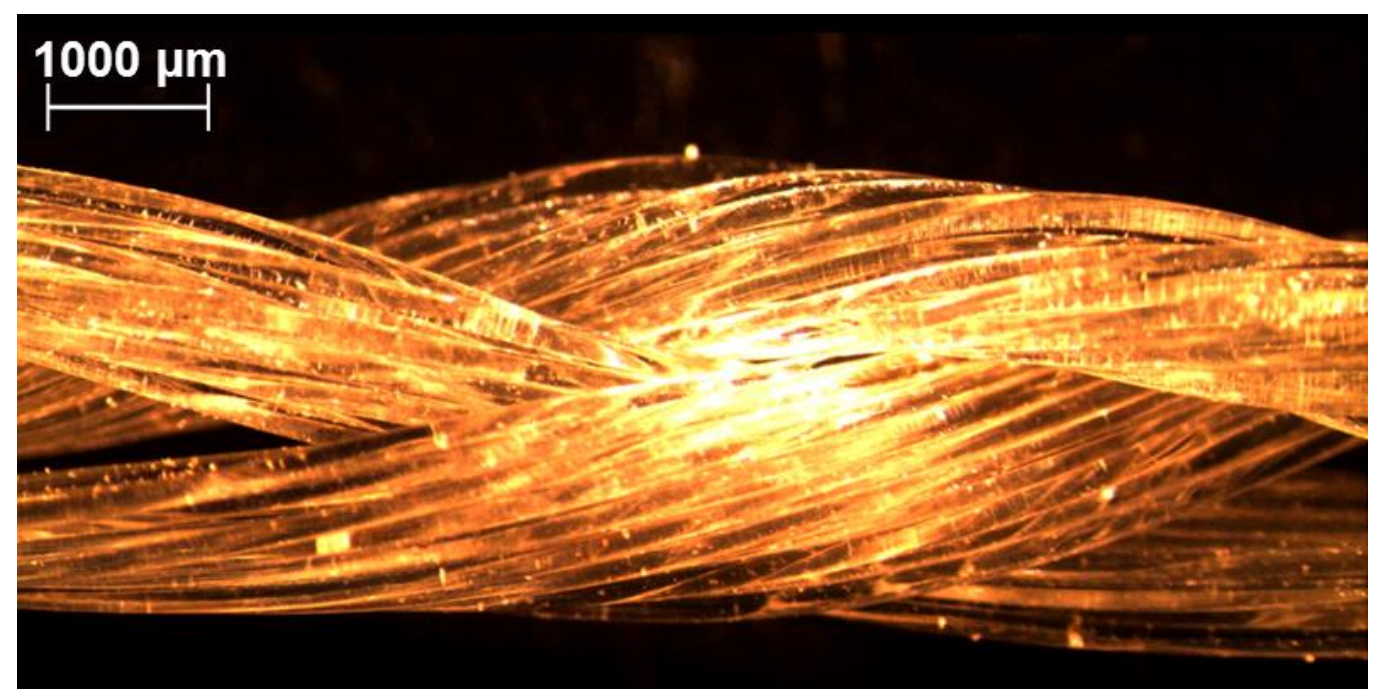

Figure 3. Optical microscopy picture of ligament tissue engineering scaffold

This observation was confirmed by analysis of the mechanical properties obtained from these curves (Table 1). Compared to the fibers, scaffolds' Young's modulus (E) strongly decreased whereas yield strain $\left(\varepsilon_{y}\right)$ and strain at failure $\left(\varepsilon_{f}\right)$ increased. By giving microfibers the ability to slide 
along each other, the twisting-braiding processing induced these changes and allowed us to obtain properties closer to the ACL ones. Interestingly, 94P200 and 94T200 copolymers had different behaviors concerning yield stress $\left(\sigma_{y}\right)$ and stress at failure $\left(\sigma_{f}\right)$ after processing. Indeed, values significantly decreased for linear 94P200 copolymer (from 29 to $19 \mathrm{MPa}$ and from 33 to $24 \mathrm{MPa}$ ) whereas they slightly increased for star 94T200 copolymer (from 16 to $21 \mathrm{MPa}$ and from 22 to 29 MPa). Despite this difference, both types of scaffolds showed stresses at failure which were compatible with ACL range of values $(14-36 \mathrm{MPa}) \cdot{ }^{[29]}$ On the other hand, Young's modulus, yield strain and strain at failure values measured on 94P200 scaffolds seemed more adapted to the ACL requirements. Strain at failure values obtained with 94T200 scaffolds were low (20\%) compared to 94P200 samples (78 \%) and ACL (19 - 36\%). Finally, yield strain value for 94P200 scaffold (6\%) was close to the lower range value for ACL (7\%), and this characteristic may be further improved by tuning the scaffold shape in the future. All these observations led us to focus on 94P200 samples for the following experiments as properties were in agreement with those described by Laurencin $e t$ al. who developed scaffolds made from PLA fibers with architectures close to ours. ${ }^{[31]}$ Their 4 braid 60-72 scaffold, which was considered as the best sample by the authors, exhibited a higher value of stress at failure (82 $\mathrm{MPa}$ ) than our own scaffolds but the copolymerization of PLA and Pluronic allowed 94P200 scaffolds to reach higher values of Young's modulus and strain at failure (respectively $745 \mathrm{MPa}$ and $31 \%$ for the 4 braid 60-72 sample). In addition, degradation being a key point for this approach, the possibility to modulate the degradation rate thanks to the copolymers ${ }^{[31]}$ appears as an interesting alternative to pure crystalline PLA scaffolds. 

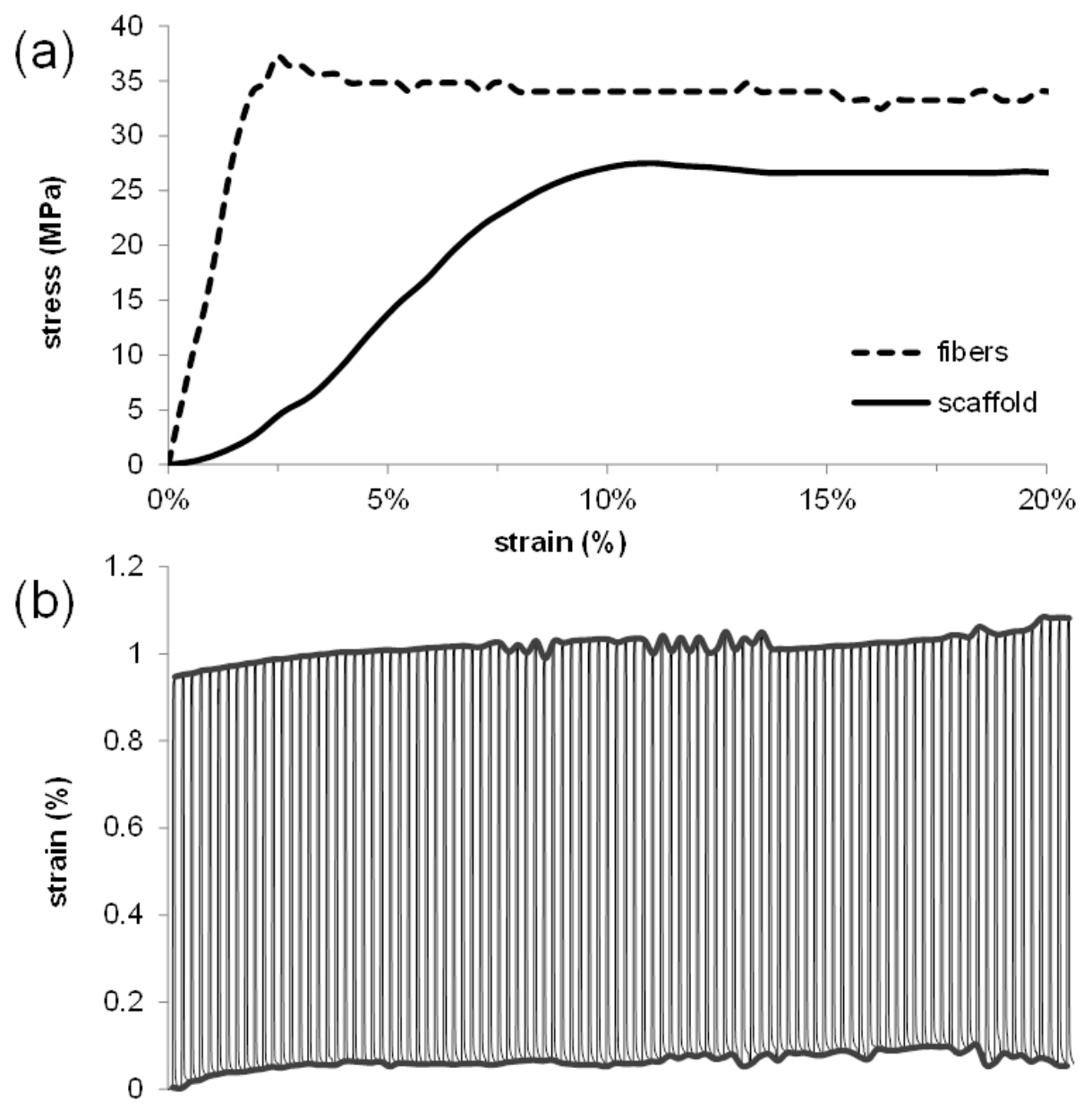

Figure 4. Mechanical properties (a) typical stress-strain curves of extruded microfibers and twistedbraided scaffolds (b) evolution of the strain of a twisted-braided scaffold submitted to cyclic loads

Dynamic mechanical tests were finally performed to assess the ability of such twisted-braided scaffolds to withstand cyclic loadings. Scaffolds were submitted to 100 creep/recovery cycles including a $1 \mathrm{MPa}$ tensile stress phase (30 seconds) followed by a release of the applied load and a recovery period (90 seconds). Figure $\mathbf{4 b}$ shows the evolution of the strain of a 94P200-based scaffold during these cycles and highlights the maximal and the residual strains. This test demonstrated that the scaffolds were able to bear such restrained loads at least a hundred times without breaking. Furthermore, it could be noticed that maximum and residual strains increased moderately through time. Maximal strain increased from $0.95 \%$ to $1.08 \%$ whereas residual strain was limited to $0.07 \%$. 


\subsection{Cytocompatibility}

Despite the proven cytocompatibility of PLA, Pluronic, Tetronic and their copolymers with L929 fibroblasts, ${ }^{[19,32]}$ viability and proliferation of C3 MSCs were assessed on 94P200 and 94T200 twisted-braided scaffolds. First, proliferation of C3 MSCs seeded on scaffolds or in TCPS wells (positive control) was compared using the PrestoBlue assay during a 14-day period. As shown in Figure 5, C3 MSCs highly proliferated during the overall period for all scaffolds. Starting from the $10^{\text {th }}$ day, it can even be noticed that the fluorescence expressed with respect to the estimated available proliferation surface is statistically higher on copolymer scaffolds than on TCPS positive control. Not only this result demonstrated the excellent cytocompatibility of scaffolds made with 94P200 and 94T200 copolymers, but also suggested that the twisted-braided shape did not cause any significant loss of cell viability and enhanced cell proliferation.

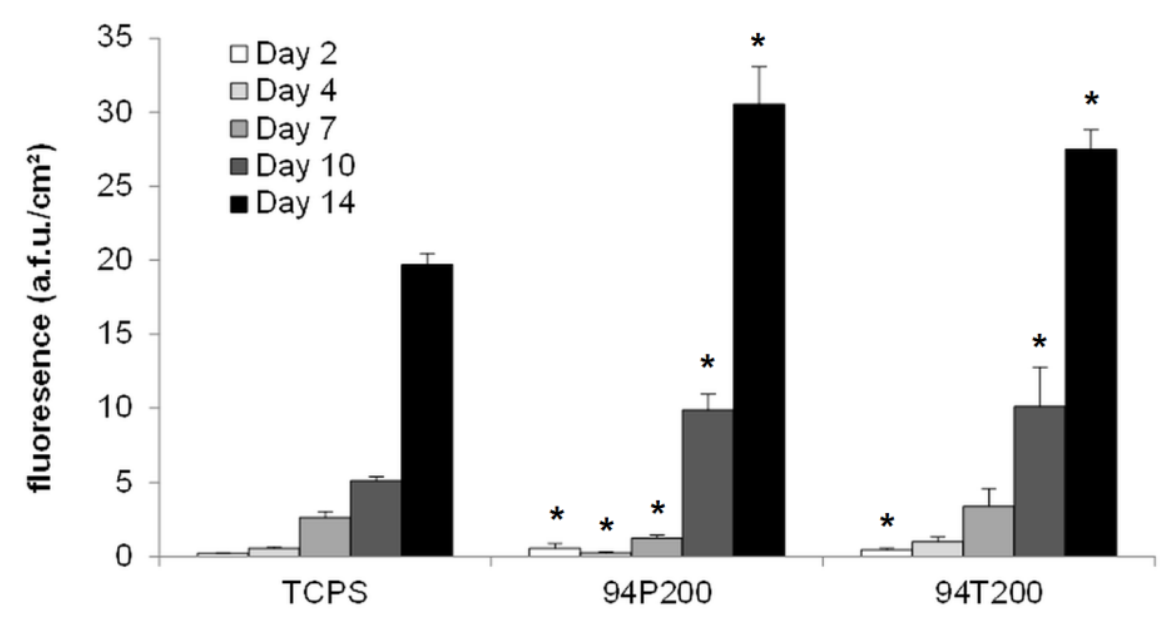

Figure 5. In vitro proliferation of $\mathrm{C} 3$ cells on copolymers scaffolds. *Statistically significant difference in comparison with the TCPS control at the same time $(p<0.05)$

Cell survival was also evaluated using the Live/Dead assay and confocal microscopy observations of scaffolds seeded with C3 MSCs. As shown in Figure 6, after 10 days of culture, living C3 MSCs widely covered the surface of the scaffold. Moreover, almost no red staining was observed, confirming the absence of cytotoxic effect due to the copolymer. Living cells were also observed 
between the fibers inside the scaffold (Supporting Information MovieS1) indicating a threedimensional colonization of the twisted-braided structure. In conclusion, the data demonstrated adhesion and survival of cells, high proliferation and 3D colonization by C3 MSCs, indicating an excellent cytocompatibility of the scaffolds and making them promising substrates for MSCs proliferation and differentiation.
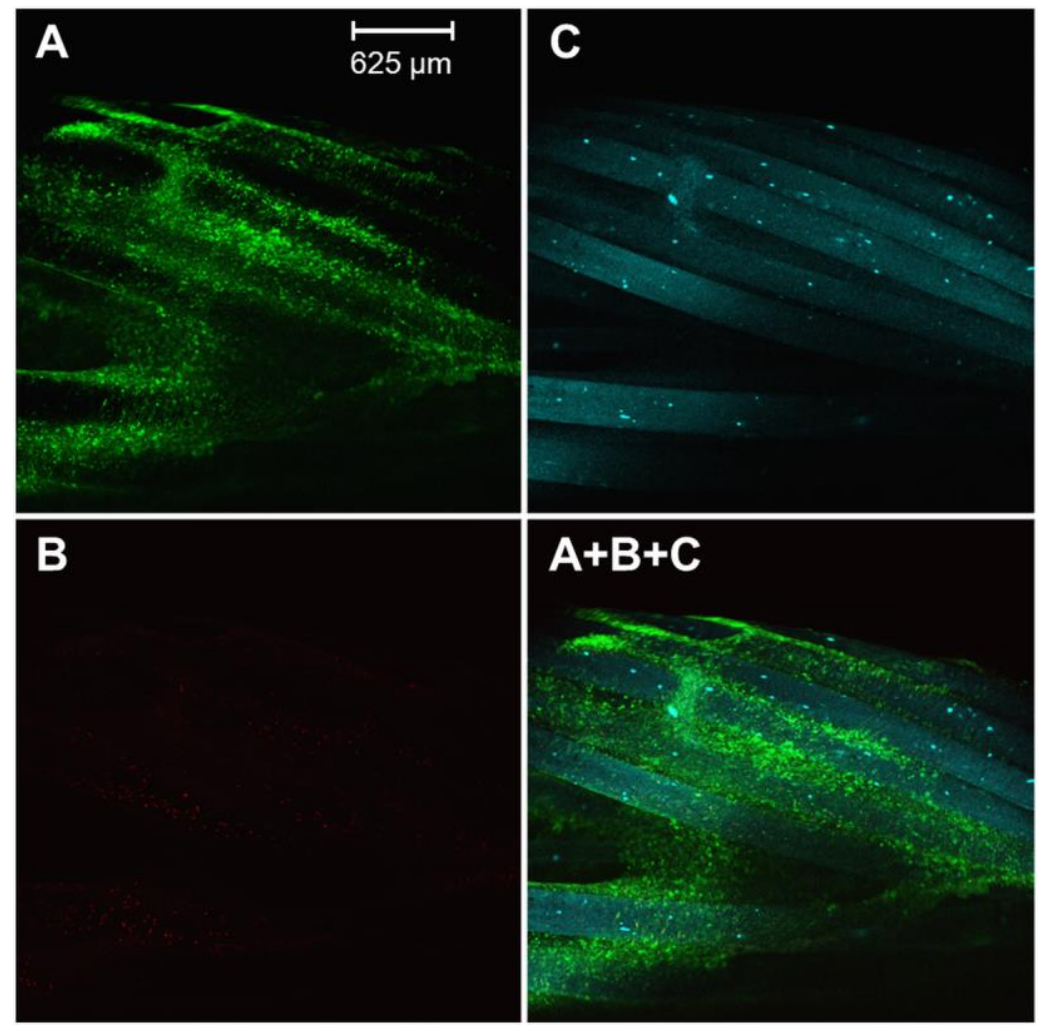

Figure 6. Live/Dead assay fluorescent microscopy pictures after 10 days of proliferation of C3 cells on 94P200 scaffold: staining highlights viable cells in green (A), dead cells in red (B) and copolymer autofluorescence in blue (C).

\subsection{Differentiation assays with inductive medium}

A first differentiation test was carried out on TCPS with C3 MSCs with three objectives: to assess the level of spontaneous differentiation in the absence of inductive medium, to assess the efficiency of the inductive medium containing ascorbic acid and $\beta$-glycerophosphate and to find the most suitable cell seeding density. The RT-qPCR analyses which were performed during the 21 days of 
culture revealed that the inductive effect of this culture medium was strongly dependent on cell density. When cells were seeded at a high density $\left(80 \times 10^{3}\right.$ cells/well), most of the differentiation markers (Col I, Col III, Tnmd and Scx) were not modulated by the inductive medium (Supporting Information Figure S3). Expression of Tnc even decreased after the $7^{\text {th }}$ day and remained downregulated until the end of the experiment. On the other hand, significant upregulation of all the differentiation markers, except Scx, was noticed on cells seeded at a lower density $\left(16 \times 10^{3}\right.$ cells/well) during the first 14 days. Interestingly, expression of Tnc and Tnmd was significantly upregulated at an earlier time point in inductive medium as compared to control condition (peak at day 10 for Tnc and day 3 for Tnmd). No significant modulation of Scx was observed, although it seemed slightly increased at day 3 by the inductive medium with cells seeded at the lowest density. These results indicated that the selected inductive culture medium significantly upregulated the expression levels of most characteristic markers of the ligament fibroblast and therefore stimulated phenotypic orientation of C3 MSCs.

Consequently, another experiment was performed to evaluate the influence of the culture substrate and confirm the importance of seeding density on differentiation (Figure 7). C3 MSCs were seeded at both densities $\left(16 \times 10^{3}\right.$ and $80 \times 10^{3}$ cells/well) on 94P200 scaffolds (chosen for their better mechanical properties) and TCPS wells and maintained in inductive medium. Whatever the seeding density, expression levels of Col I and Col III increased during the experiment but were significantly lower on scaffolds than on TCPS. On the contrary, a significant increased expression of key ligamentocyte markers Tnc and Tnmd was observed at different time points during the assay when cells were seeded on scaffold or on TCPS. The expression of the markers by cells seeded on scaffold were however statistically higher on day 7 and 21 for Tnc and, day 3 and 21 for Tnmd. Although the expression of Scx decreased during the culture, it was higher on scaffolds than on TCPS during all the experiment. Importantly with cells seeded on scaffolds, expression of the markers (in particular Tnc, Tnmd and Scx) remained stable or even increased by day 21 suggesting a sustained differentiation supportive effect of the scaffold. These results indicated that a low cell 
density favored differentiation of C3 MSCs when cultured in inductive medium suggesting the importance of a proliferation phase for better commitment toward the ligamentocyte lineage. All the differentiation markers, with the exception of Scx, were increased when MSCs were cultured on scaffolds even though Col I and Col III were expressed at lower levels as compared to TCPS. Notably, the higher expression of Tnc, Tnmd and Scx, which are more specific for ligamentocytes, on scaffolds as compared to TCPS indicated that scaffolds were suitable for ligamentocyte differentiation.
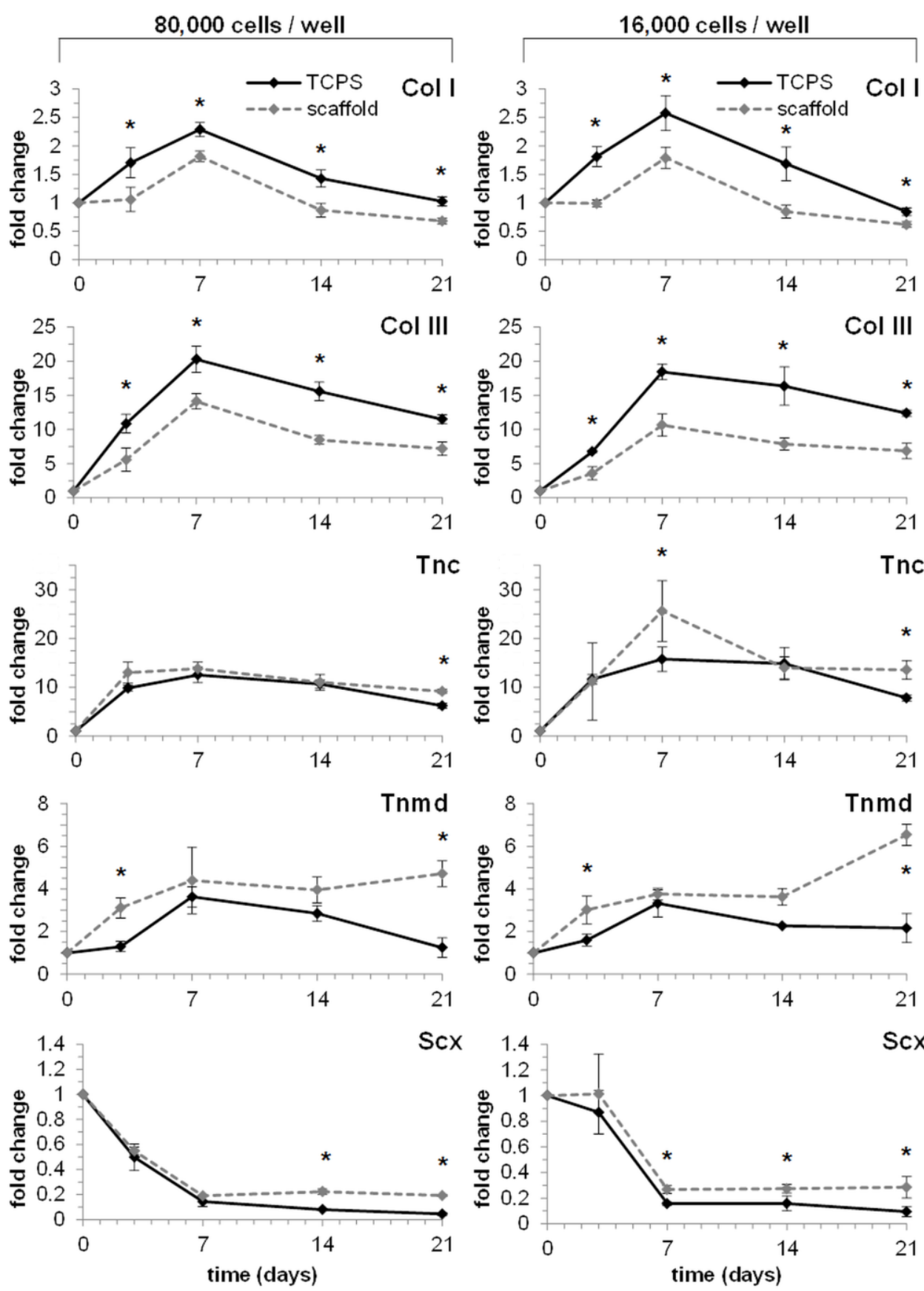
Figure 7. Cell differentiation - expression of fibroblast-related markers by $\mathrm{C} 3$ cells maintained in inductive culture medium on TCPS or twisted-braided scaffold versus time $(p<0.05)$

\subsection{Differentiation assays with inductive medium and mechanical stimulation}

After having determined inductive conditions and in order to enhance ligamentocyte differentiation, we investigated the effect of a cyclic mechanical stimulation procedure applied to scaffolds. It was previously demonstrated that such stimulation processes may induce cellular responses including differentiation toward a ligamentocyte phenotype. ${ }^{[22,33]}$ The behavior of cells cultured on these scaffolds under mechanical stimulation during 14 days was compared with that of cells cultured on scaffolds without any mechanical stimulation. As shown in Figure 8, the mechanical stimulation did not improve the expression of Col I and led to a similar increase of Col III expression during the experiment to the one observed for non-stimulated cells. On the other hand, Tnc and Tnmd were significantly upregulated with expression peaks at $7^{\text {th }}$ day of culture while Scx was upregulated during the whole experiment. Importantly, we observed the increase of Scx expression compared to cells at the beginning of the test uniquely on cells cultured on scaffolds under stimulation $(1.3 \pm 0.2$ fold increase at day 3 with respect to day 0 control). It should be noted that most of these results are in agreement with those presented by Subramony et al. in a similar study ${ }^{[17]}$. These authors also described a late upregulation of Col III, Tnc and Scx after 14 days of culture on aligned nanofibers of PLGA under mechanical stimulation in comparison with non-stimulated control samples. 

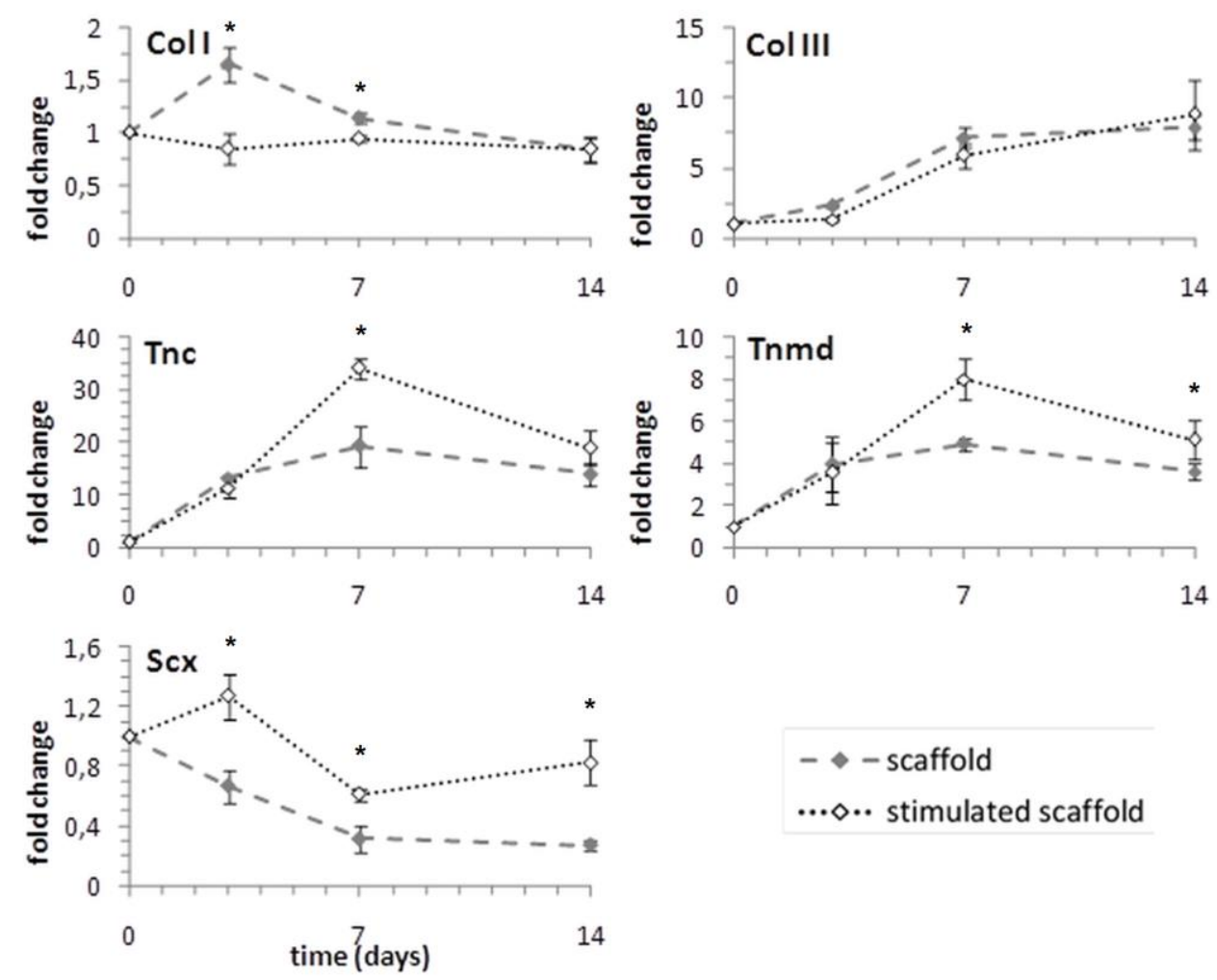

Figure 8. Cell differentiation - expression of fibroblast-related markers by $\mathrm{C} 3$ cells maintained in inductive culture medium on scaffold as a function of the mechanical stimulation versus time $(p<$ $0.05)$

In summary, although expression of Col I and Col III was not enhanced by the mechanical stimulation, that of other ligamentocyte markers did. Interestingly, mechanical stimulation induced a higher expression of Scx, an early transcription factor leading to the formation of ligament and tendon tissues, ${ }^{[34]}$ and of Tnmd, a transmembrane protein and late marker of tendon and ligament formation regulated by Scx expression. ${ }^{[35]}$ All these results suggested that the association of inductive medium and mechanical stimulation promoted the commitment of MSCs toward a ligament fibroblast phenotype. It is important to note that all the experiments were performed with murine mesenchymal stromal cells C3H10T1/2 that are currently used to evaluate the influence of scaffolds or molecules on cell differentiation. ${ }^{[36]}$ Future work should confirm these promising results by assessing in vitro and in vivo long-term expression levels of markers from primary bone marrowisolated mesenchymal stromal cells. 


\section{Conclusion}

This work describes the development of prototype twisted-braided scaffolds for ligament tissue engineering based on original PLA-Pluronic or PLA-Tetronic architectures with intermediate degradation rates. These scaffolds obtained by twisting and braiding of copolymers microfibers exhibited mechanical properties close to those of a human ACL. They also proved to be able to withstand cyclic mechanical loadings and to have a high cytocompatibility with C3 MSCs. The Pluronic-based scaffolds were further shown to support MSC differentiation toward the ligament fibroblast phenotype when cells were cultured in inductive medium, and proper cell seeding density. Finally, scaffolds subjected to cyclic mechanical stimulation further stimulated the differentiation of MSCs. The increased expression levels of ligamentocyte lineage markers and especially that of Scleraxis, a key marker of ligament and tendon differentiation, demonstrated the potential of the proposed scaffolds together with mechanical stimulation for future development of ligament tissue engineering.

\section{Experimental section}

\subsection{Materials}

Poloxamine (Tetronic ${ }^{\circledR} 1107 ; 15,000 \mathrm{~g} / \mathrm{mol}$ ) was purchased from BASF (Levallois Perret, France). Poloxamer (Pluronic $^{\circledR}$ F-127 ; 12,600 g/mol), tin(II) 2-ethylhexanoate ( $\left.\mathrm{Sn}(\mathrm{Oct}) 2,95 \%\right)$, dichloromethane (DCM), diethyl ether and tetrahydrofuran (THF) were purchased from SigmaAldrich (St-Quentin Fallavier, France), L-lactide (L-LA) and D,L-lactide (DL-LA) were purchased from Purac (Lyon, France). PrestoBlue ${ }^{\mathrm{TM}}$, Dulbecco's Modified Eagle Medium (DMEM) DMEM/ F-12, Phosphate Buffered Saline (PBS), Dulbecco's Phosphate Buffered Saline (DBPS), Foetal Bovine Serum (FBS), penicillin, streptomycin, and glutamine were purchased from Invitrogen (Cergy Pontoise, France). BD Falcon ${ }^{\mathrm{TM}}$ Tissue Culture Polystyrene (TCPS) multiwell plates were purchased from Becton Dickinson (Le Pont de Claix, France) and Corning ${ }^{\circledR}$ Costar $^{\circledR}$ Ultra Low 
Attachment (ULA) multiwell plates from Sigma-Aldrich. All chemicals and solvents were used without purification.

\subsection{Copolymers syntheses and degradation}

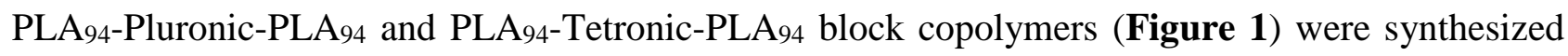
by ring-opening polymerization (ROP) following a procedure previously described by our group. ${ }^{[19]}$ Typically, predetermined amounts of L-LA, DL-LA and Pluronic or Tetronic were introduced into a flask and $\mathrm{Sn}(\mathrm{Oct})_{2}(0.1$ molar \% with respect to LA units) was then added. After degassing, the flask was sealed under vacuum and polymerization was allowed to proceed at $110^{\circ} \mathrm{C}$. After 5 days, the copolymer was recovered by dissolution in DCM and precipitation in cold diethyl ether. Finally, the product was dried under reduced pressure to constant mass. The copolymers were obtained with an average yield of $81 \%$ (40.5 g).

${ }^{1} \mathrm{H}$ NMR: (300 MHz; $\left.\mathrm{CDCl}_{3}\right): \delta(\mathrm{ppm})=5.1\left(\mathrm{q}, 1 \mathrm{H}, \mathrm{CO}-\mathrm{CH}\left(\mathrm{CH}_{3}\right)-\mathrm{O}\right), 3.6\left(\mathrm{~s}, 4 \mathrm{H}, \mathrm{CH}_{2}-\mathrm{CH}_{2}-\mathrm{O}\right), 3.5$ (m, 2H, $\left.\mathrm{CH}\left(\mathrm{CH}_{3}\right)-\mathrm{CH}_{2}-\mathrm{O}\right), 3.4\left(\mathrm{~m}, 1 \mathrm{H}, \mathrm{CH}\left(\mathrm{CH}_{3}\right)-\mathrm{CH}_{2}-\mathrm{O}\right), 1.5\left(\mathrm{~m}, 3 \mathrm{H}, \mathrm{CO}-\mathrm{CH}\left(\mathrm{CH}_{3}\right)-\mathrm{O}\right), 1.1$ (m, $\left.3 \mathrm{H}, \mathrm{CH}\left(\mathrm{CH}_{3}\right)-\mathrm{CH}_{2}-\mathrm{O}\right)$.

Polymerization degree of PLA blocks and molecular weight of the synthesized block copolymers were calculated using the following equations.

$$
\mathrm{DP}_{\mathrm{PLA}}=\mathrm{DP}_{\mathrm{PEO}} /(\mathrm{EO} / \mathrm{LA})
$$

\section{Equation 1}

For PLA-Pluronic-PLA copolymers:

$$
M_{n}=2 \times(\text { DPPLA } \times 72)+M_{n} \text { Pluronic }
$$

\section{Equation 2}

For PLA-Tetronic-PLA copolymers:

$$
M_{n}=4 \times(\text { DPPLA } x 72)+M_{n} \text { Tetronic }
$$

\section{Equation 3}

EO/LA being the ratio of ethylene oxide and lactyl units and PO/LA the ratio of propylene oxide and lactyl units calculated from ${ }^{1} \mathrm{H}$ NMR spectra.

For tensile tests and degradation tests on films, sample plates were prepared by compression of the polymer in stainless steel mould for $10 \mathrm{~min}$ at $200^{\circ} \mathrm{C}$ and 8 tons using a Carver press (4120). 
For degradation test samples were cut $(30 \times 10 \times 0.5 \mathrm{~mm})$ and were then placed in $8 \mathrm{~mL}$ of PBS $(\mathrm{pH}$

7.4) at constant temperature $\left(37^{\circ} \mathrm{C}\right)$ under stirring. At scheduled time points, samples were removed from PBS, dried to constant mass before SEC analysis for molecular weights determination.

\subsection{Scaffold design}

Micro-fibers were obtained by processing the copolymers with a DSM Xplore equipment combining a micro-compounder and a micro-fiber spin device kindly made available by Pr Sophie Duquesne from the Ecole Nationale Supérieure de Chimie de Lille (ENSCL) and the Unité Matériaux et Transformations (UMET - UMR CNRS 8207). In order to obtain microfibers, $20 \mathrm{~g}$ of PLA-Pluronic or PLA-Tetronic copolymer were introduced in a DSM Xplore twin-screw microcompounder equipped with an extrusion chamber of $15 \mathrm{~mL}$ and co-rotating twin-screws maintained under a nitrogen flow. First, the temperature of the extrusion chamber was set at $200^{\circ} \mathrm{C}$ and the screw speed at $80 \mathrm{rpm}$ for around 5 minutes. The extrusion was then realized at a screw speed of 15 rpm through a $1 \mathrm{~mm}$ diameter spinneret and the monofilament was drawn and collected using a DSM Xplore Fiber Spin Line equipped with a drawing roll and a collecting roll (spinning velocity of $30 \mathrm{~m} / \mathrm{min})$.

Extruded micro-fibers were used to make fibrous scaffolds thanks to a method combining twisting and braiding processes. To prepare one scaffold, 30 micro-fibers were first cut in long segments (75 $\mathrm{cm})$ and separated in 3 groups. Each group of 10 micro-fibers was twisted for 10 seconds in a clockwise direction using a rotary engine. The 3 bundles were then braided together to form the scaffold (Figure 3).

\subsection{Characterizations}

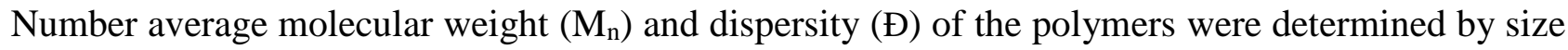
exclusion chromatography (SEC) using a Viscotek GPCMax autosampler system fitted with two Viscotek LT5000L Mixed Medium columns $(300 \times 7.8 \mathrm{~mm})$, and a Viscotek VE 3580 RI detector. 
The mobile phase was $\mathrm{THF}$ at $1 \mathrm{~mL} / \mathrm{min}$ flow and $30^{\circ} \mathrm{C}$. Typically, the polymer $(20 \mathrm{mg})$ was dissolved in THF ( $2 \mathrm{~mL})$ and the resulting solution was filtered through a $0.45 \mu \mathrm{m}$ Millipore filter before injection of $20 \mu \mathrm{L}$ of filtered solution. $\mathrm{M}_{\mathrm{n}}$ and $Đ$ were expressed according to calibration using Polystyrene standards.

${ }^{1} \mathrm{H}$ NMR spectra were recorded at room temperature using an AMX300 Bruker spectrometer operating at $300 \mathrm{MHz}$. Deuterated chloroform was used as solvent, chemical shifts were expressed in ppm with respect to tetramethylsilane (TMS).

Differential scanning calorimetry (DSC) measurements were carried out under nitrogen on a Perkin Elmer Instrument DSC 6000 thermal analyzer. Samples were submitted to a first heating scan to $200{ }^{\circ} \mathrm{C}$ followed by a cooling $\left(10{ }^{\circ} \mathrm{C} \cdot \mathrm{min}^{-1}\right.$ from $200{ }^{\circ} \mathrm{C}$ to $100{ }^{\circ} \mathrm{C}$, and $5{ }^{\circ} \mathrm{C} \cdot \mathrm{min}^{-1}$ from $100{ }^{\circ} \mathrm{C}$ to $30{ }^{\circ} \mathrm{C}$ ) and a second heating scan to $200{ }^{\circ} \mathrm{C}\left(10^{\circ} \mathrm{C} \cdot \mathrm{min}^{-1}\right)$. Glass transition temperature $\left(\mathrm{T}_{\mathrm{g}}\right)$, melting temperature $\left(\mathrm{T}_{\mathrm{m}}\right)$ and melting enthalpy $\left(\Delta \mathrm{H}_{\mathrm{m}}\right)$ were measured on the second heating ramp. Tensile mechanical tests were performed on scaffold samples and on groups of 10 parallel isolated micro-fibers. Samples $(30 \mathrm{~mm})$ were analyzed at $37^{\circ} \mathrm{C}$ in an Instron 4444 at a crosshead speed rate of $5 \mathrm{~mm} / \mathrm{min}$, each sample being loaded to failure. Samples were analyzed in triplicate and Young's modulus $(\mathrm{E}, \mathrm{MPa})$, stress at failure $\left(\sigma_{\mathrm{f}}, \mathrm{MPa}\right)$, strain at failure $\left(\varepsilon_{\mathrm{f}}, \%\right)$, yield stress $\left(\sigma_{\mathrm{y}}, \mathrm{MPa}\right)$, and yield strain $\left(\varepsilon_{y}, \%\right)$ were expressed as the mean value of the three measurements. E was calculated using the second linear portion of the stress-strain curves corresponding to ACL's linear region (Supporting Information Figure S1).

Dynamic tensile mechanical tests were also performed on scaffolds to study their resistance to cyclic mechanical loading. Samples $(10 \mathrm{~mm})$ were analyzed at $37^{\circ} \mathrm{C}$ in a Perkin Elmer Instrument DMA 7 mechanical analyzer. Samples were submitted to 100 creep/recovery cycles (1 MPa tensile stress during 30 seconds followed by a release of the applied load and a recovery period of 90 seconds). 


\subsection{Cell culture}

Murine mesenchymal stromal cells C3H10T1/2 (designated C3 MSCs thereafter) were used to assess the in vitro cytocompatibility of the scaffolds and to carry out the differentiation tests. Cells were cultured in a $5 \% \mathrm{CO}_{2}$ incubator at $37{ }^{\circ} \mathrm{C}$ in proliferative medium composed of DMEM with phenol red (+PR) or DMEM / F-12 without phenol red (-PR) supplemented with 10\% FBS, penicillin $(100 \mathrm{U} / \mathrm{mL})$, streptomycin $(100 \mu \mathrm{g} / \mathrm{mL})$ and glutamine $(2 \mathrm{mM})$. All scaffold samples used in these studies were disinfected in ethanol for $30 \mathrm{~min}$ before immersion in a solution of sterile PBS containing penicillin and streptomycin $(1 \mathrm{mg} / \mathrm{mL})$ and incubation for $48 \mathrm{~h}$ at $37{ }^{\circ} \mathrm{C}$. Samples were then rinsed 2 times with sterile PBS before soaking for $12 \mathrm{~h}$ in sterile PBS.

\subsection{Cytocompatibility}

To evaluate the proliferation potential of $\mathrm{C} 3$ cells, samples (10 $\mathrm{mm}$ long) were cut from scaffolds and placed in ULA 6-well plates to avoid cells growing on the bottom of the wells. Samples and empty TCPS 6-well plates were seeded with $10^{4} \mathrm{C} 3$ cells which were then maintained in proliferative medium (-PR). Viability and proliferation were evaluated after 2, 4, 7, 10 and 14 days using PrestoBlue assay, a cell-permeable resazurin-based viability reagent which reflects the number of living cells present at a given time point. At scheduled time points, proliferative medium was removed and replaced by $5 \mathrm{~mL}$ of fresh medium containing $10 \%$ of PrestoBlue. After 30 minutes of incubation at $37^{\circ} \mathrm{C}, 200 \mu \mathrm{L}$ of supernatant were taken and analyzed for fluorescence (excitation $560 \mathrm{~nm}$, emission $590 \mathrm{~nm}$ ) with a Varioskan Flash Multimode microplate reader (Thermo Scientific, Waltham, USA). Results were divided by the estimated surface available for cell proliferation $\left(9.4 \mathrm{~cm}^{2}\right.$ for TCPS wells, $1.5 \mathrm{~cm}^{2}$ for 94P200 scaffolds and $1.8 \mathrm{~cm}^{2}$ for 94T200 scaffolds) and expressed as arbitrary fluorescence unit (a.f.u. / $\left.\mathrm{cm}^{2}\right)$.

Cell adhesion and viability were assessed using the PromoKine Live/Dead cell staining kit (PromoCell GmbH, Heidelberg, Germany). After culture in proliferative medium $(+\mathrm{PR}), 4 \times 10^{5}$ cells were seeded on disinfected scaffold samples $(15 \mathrm{~mm})$ placed in ULA 24-well plates. After 10 
days, proliferative medium was removed and samples were rinsed 3 times with sterile PBS to eliminate non-adherent cells. C3 cells were then incubated in the presence of Live/Dead staining solution ( $2 \mu \mathrm{M}$ Calcein-AM and $4 \mu \mathrm{M}$ Ethidium homodimer III) at $37^{\circ} \mathrm{C}$ for $15 \mathrm{~min}$ and then fixed with $4 \%$ paraformaldehyde for $10 \mathrm{~min}$. Cells were observed under a Leica Microsystems Macroconfocal LSI microscope (Leica Microsystems GmbH, Wetzlar, Germany).

\subsection{Differentiation tests}

Differentiation of C3 MSCs was induced after seeding at different densities $\left(16 \times 10^{3}\right.$ and $80 \times 10^{3} \mathrm{C} 3$ cells) on TCPS and culture in inductive medium composed of proliferative medium $(+\mathrm{PR})$ supplemented with ascorbic acid $(50 \mu \mathrm{g} / \mathrm{mL})$ and $\beta$-glycerophosphate $(10 \mathrm{mM})$ or in proliferative medium (+PR) (negative control). At scheduled time points (3, 7, 10,14 and 21 days), cells were trypsinized and recovered for RNA analysis by RT-qPCR.

To study the influence of the culture substrate on the cells, $16 \times 10^{3} \mathrm{C} 3 \mathrm{MSC}$ were seeded in empty TCPS 24-well plates or on disinfected scaffold samples $(15 \mathrm{~mm})$. Cells were maintained in inductive medium for 3, 7, 10, 14 and 21 days. At scheduled time points, cells were trypsinized and recovered for RNA analysis by RT-qPCR.

For mechanical stimulation, samples $(55 \mathrm{~mm})$ were cut from scaffolds and used to obtain loops by welding their ends together. After disinfection, these loops were placed in ULA 6-well plates, seeded with $58 \times 10^{3} \mathrm{C} 3$ cells which were then maintained in proliferative medium $(+\mathrm{PR})$. After 2 days (day 0), proliferative medium was replaced by inductive medium and seeded loops were maintained under static conditions (negative control) or dynamic mechanical conditions. The mechanical stimulation process consisted in a $5 \%$ cyclic strain applied at $0.5 \mathrm{~Hz}$ for 1 hour every 1 or 2 days. Cyclic strains were applied in culture medium thanks to a N-381 NEXACT ${ }^{\circledR}$ piezoelectric motor (Physik Instrumente $\mathrm{GmbH} \& \mathrm{Co}$, Karlsruhe, Germany) able to generate an up to $10 \mathrm{~N}$ force (Supporting Information Figure S4). After 3 (3 sessions of stimulation), 7 (4 sessions) and 14 days (7 sessions), cells were trypsinized for RNA analysis by RT-qPCR. 


\subsection{Total RNA extraction and RT-qPCR}

C3 cells were washed with PBS and mechanically dissociated in lysis buffer for total RNA extraction using the RNeasy Mini Kit and a QIAcube automated station according to the manufacturer's instructions (Qiagen S.A., Courtabœuf, France). RNA (0.5 to $1 \mu \mathrm{g}$ ) was reverse transcribed using the M-MLV enzyme (Life technologies, Saint-Aubin, France). Primers were designed using Primer3 software (Supporting Information Table S2) and purchased from MWG (Eurofins genomics, Courtabœuf, France). PCR reaction was carried out on $20 \mathrm{ng}$ of cDNA samples using $5 \mu \mathrm{mol} / \mathrm{L}$ of each primer. Real-time PCR was performed using the SYBR Green I Master Kit and a LightCycler ${ }^{\circledR} 480$ detection system, following the manufacturer's recommendations and analysis of mRNA expression level was performed using the dedicated software (Roche Applied Science, Meylan, France). Expression level of transcripts was normalized to the glyceraldehyde-3phosphate dehydrogenase (GAPDH) housekeeping gene and expressed as fold change according to the formulae $2^{-\Delta \Delta \mathrm{Ct}}$.

\subsection{Statistical analyses}

Results corresponded to separate experiments done in triplicate and values are given as mean \pm SD. Statistical analyses were performed with the GraphPad Prism software (San Diego, CA). Comparison between several groups used a non-parametric Mann-Whitney test (a level of $p<0.05$ was considered statistically significant).

\section{Supporting Information}

Supporting Information is available from the Wiley Online Library or from the author.

\section{Acknowledgements}

The authors thank the French Ministry of Higher Education and Research for Adrien Leroy's fellowship. The authors would also like to thank Prof. Sophie Duquesne and Mathieu Coquelle (ENSCL and UMET - UMR CNRS 8207) for making the microextrusion device available for this 
project. Work in the laboratory Inserm U844 was supported by the Inserm Institute, the University of Montpellier I. We also thank the Agence Nationale pour la Recherche for support of the national infrastructure: "ECELLFRANCE: Development of a national adult mesenchymal stem cell based therapy platform" (ANR-11-INSB-005). 


\section{References}

[1] a) V. B. Duthon, C. Barea, S. Abrassart, J. H. Fasel, D. Fritschy, J. Ménétrey, Knee Surg. Sports Traumatol. Arthrosc. 2006, 14, 204; b) T. Zantop, W. Petersen, J. Sekiya, V. Musahl, F. Fu, Knee Surg. Sports Traumatol. Arthrosc. 2006, 14, 982 ; c) M.M. Murray, B.C. Fleming J. Orthop. Res. 2013, 31, 1501.

[2] N. L. Leong, F. A. Petrigliano, D. R. McAllister, J. Biomed. Mater. Res. Part A 2013, 102, 1614.

[3] J. Cournapeau, S. Klouche, P. Hardy, Orthop. Traumatol. Surg. Res. 2013, 99, 196.

[4] a) C. Legnani, A. Ventura, C. Terzaghi, E. Borgo, W. Albisetti, Int. Orthop. 2010, 34, 465; b) A. Ventura, C. Terzaghi, C. Legnani, E. Borgo, W. Albisetti, The Knee 2010, 17, 108.

[5] a) X. Chen, Y.-Y. Qi, L.-L. Wang, Z. Yin, G.-L. Yin, X.-H. Zou, H.-W. Ouyang, Biomaterials 2008, 29, 3683; b) E. T. Ricchetti, A. Aurora, J. P. Iannotti, K. A. Derwin, J. Shoulder Elb. Surg. 2012, 21, 251.

[6] a) S. Farè, P. Torricelli, G. Giavaresi, S. Bertoldi, A. Alessandrino, T. Villa, M. Fini, M. C. Tanzi, G. Freddi, Mater. Sci. Eng. C 2013, 33, 3601; b) A. L. Oliveira, L. Sun, H. J. Kim, X. Hu, W. Rice, J. Kluge, R. L. Reis, D. L. Kaplan, Acta Biomater. 2012, 8, 1530.

[7] C. Vaquette, C. Kahn, C. Frochot, C. Nouvel, J.-L. Six, N. D. Isla, L.-H. Luo, J. CooperWhite, R. Rahouadj, X. Wang, J. Biomed Mater. Res. Part A 2010, 94A, 1270.

[8] a) E. Gentleman, G. Livesay, K. Dee, E. Nauman, Ann. Biomed.Eng. 2006, 34, 726; b) S. J. Kew, J. H. Gwynne, D. Enea, M. Abu-Rub, A. Pandit, D. Zeugolis, R. A. Brooks, N. Rushton, S. M. Best, R. E. Cameron, Acta Biomater. 2011, 7, 3237.

[9] a) T. Irie, T. Majima, N. Sawaguchi, T. Funakoshi, S.-I. Nishimura, A. Minami, J. Biomed. Mater. Res. Part A 2011, 97A, 111; b) A. P. Mathew, K. Oksman, D. e. Pierron, M.-F. o. Harmand, Carbohyd. Polym. 2012, 87, 2291. 
[10] H.-J. Shao, C. S. Chen, Y.-T. Lee, J.-H. Wang, T.-H. Young, J. Biomed. Mater. Res. Part A 2010, 93A, 1297.

[11] a) J. G. Barber, A. M. Handorf, T. J. Allee, W.-J. Li, Tissue Eng. Pt A 2013, 19,1265; b) J. W. Freeman, M. D. Woods, D. A. Cromer, E. C. Ekwueme, T. Andric, E. A. Atiemo, C. H. Bijoux, C. T. Laurencin, J. Biomech. 2011, 44, 694; c) N. Tovar, S. Bourke, M. Jaffe, N. S. Murthy, J. Kohn, C. Gatt, M. G. Dunn, J. Biomed. Mater. Res. Part A 2009, 93A, 738.

[12] M. R. Ladd, S. J. Lee, J. D. Stitzel, A. Atala, J. J. Yoo, Biomaterials 2011, 32, 1549.

[13] D. C. Surrao, J. C. Y. Fan, S. D. Waldman, B. G. Amsden, Acta Biomater. 2012, 8, 3704.

[14] H. H. Lu, J. A. Cooper, S. Manuel, J. W. Freeman, M. A. Attawia, F. K. Ko, C. T. Laurencin, Biomaterials 2005, 26, 4805.

[15] H.-J. Shao, Y.-T. Lee, C.-S. Chen, J.-H. Wang, T.-H. Young, Biomaterials 2010, 31, 4695.

[16] a) C. Laurent, D. Durville, D. Mainard, J.-F. Ganghoffer, R. Rahouadj, J. Mech. Behav. Biomed. 2012, 12, 184; b) J. Lee, W. I. Choi, G. Tae, Y. H. Kim, S. S. Kang, S. E. Kim, S.-H. Kim, Y. Jung, S. H. Kim, Acta Biomater. 2010, 7, 244.

[17] S. D. Subramony, B. R. Dargis, M. Castillo, E. U. Azeloglu, M. S. Tracey, A. Su, H. H. Lu, Biomaterials 2013, 34, 1942.

[18] a) I. Rashkov, N. Manolova, S. M. Li, J. L. Espartero, M. Vert, Macromolecules 1996, 29, 50; b) A. Harrane, A. Leroy, H. Nouailhas, X. Garric, J. Coudane, B. Nottelet, Biomed. Mater. $2011,6,065006$.

[19] A. Leroy, C. Pinese, C. Bony, X. Garric, D. Noël, B. Nottelet, J. Coudane, Mater. Sci. Eng. C 2013, 33, 4133.

[20] a) W. Zhu, B. Wang, Zhang Y., Ding J., Eur. Pol. J. 2005, 41, 2161 ; b) X.Y. Xiong, K.C. Tama, L.H. Gan Polymer 2005,46,1841

[21] a) M. T. Rodrigues, R. L. Reis, M. E. Gomes, J. Tissue Eng. Regen. M. 2013, 9, 673; b) G. Vunjak-Novakovic, G. Altman, R. Horan, D. L. Kaplan, Annu. Rev. Biomed. Eng. 2004, 6, 131.

[22] C. Kuo, J. Marturano, R. Tuan, Sports Med Arthrosc. Rehab. Ther. Technol. 2010, 2, 20. 
[23] J. E. Moreau, D. S. Bramono, R. L. Horan, D. L. Kaplan, G. H. Altman, Tissue Eng. Pt A 2008, 14, 1161.

[24] J. Z. Paxton, L. M. Grover, K. Baar, Tissue Eng. Pt A 2010, 16, 3515.

[25] E. W. Yates, A. Rupani, G. T. Foley, W. S. Khan, S. Cartmell, S. J. Anand, Stem Cells Int. 2012, doi:10.1155/2012/438125.

[26] E. M. Raïf, B. B. Seedhom, M. J. Pullan, T. Toyoda, Tissue Eng. 2007, 13, 629.

[27] a) A. Hoffmann, G. Pelled, G. Turgeman, P. Eberle, Y. Zilberman, H. Shinar, K. KeinanAdamsky, A. Winkel, S. Shahab, G. Navon, G. Gross, D. Gazit, J. Clin. Invest. 2006, 116, 940; b) C. A. Gregory, J. Ylostalo, D. J. Prockop, Sci. STKE 2005, 294, 37; c) B. Neuhuber, S. A. Swanger, L. Howard, A. Mackay, I. Fischer, Exp. Hematol. 2008, 36, 1176.

[28] a) A. Kowalski, A. Duda, S. Penczek, Macromolecules 1998, 31, 2114; b) M-H. Huang, S. Li, M. Vert, Polymer 2004, 45, 8675.

[29] A. C. Vieira, R. M. Guedes, A. T. Marques, J. Biomech. 2009, 42, 2421.

[30] L. Fambri, A. Pegoretti, R. Fenner, S. D. Incardona, C. Migliaresi, Polymer 1997, 38, 79.

[31] J. W. Freeman, M. D. Woods, C. T. Laurencin, J. Biomech. 2007, 40, 2029.

[32] a) H. H. Jung, K. Park, D. K. Han, J. Control. Release 2010, 147, 84; b) A. Rey-Rico, M. Silva, J. Couceiro, A. Concheiro, C. Alvarez-Lorenzo, Eur. Cell.Mater. 2011, 21, 317.

[33] a) J. E. Moreau, J. Chen, R. L. Horan, D. L. Kaplan, G. H. Altman, Tissue Eng. 2005, 11, 1887; b) J. Chen, R. L. Horan, D. Bramono, J. E. Moreau, Y. Wang, L. R. Geuss, A. L. Collette, V. Volloch, G. H. Altman, Tissue Eng. 2006, 12, 3085.

[34] a) R. Schweitzer, J. H. Chyung, L. C. Murtaugh, A. E. Brent, V. Rosen, E. N. Olson, A. Lassar, C. J. Tabin, Development 2001, 128, 3855; b) P. Cserjesi, D. Brown, K. L. Ligon, G. E. Lyons, N. G. Copeland, D. J. Gilbert, N. A. Jenkins, E. N. Olson, Development 1995, 121, 1099.

[35] a) C. Shukunami, A. Takimoto, M. Oro, Y. Hiraki, Dev. Biol. 2006, 298, 234; b) D. Docheva, E. B. Hunziker, R. Fässler, O. Brandau, Mol. Cell. Biol. 2005, 25, 699. 
[36] a) A. Hoffmann, G. Pelled, G. Turgeman, P. Eberle, Y. Zilberman, H. Shinar, K. KeinanAdamsky, A. Winkel, S. Shahab, G. Navon, G. Gross, D. Gazit, J. Clin. Invest. 2006, 116, 940; b) D. Noël, D. Gazit, C. Bouquet, F. Apparailly, C. Bony, P. Plence, V. Millet, G. Turgeman, M. Perricaudet, J. Sany, C. Jorgensen, Stem Cells 2004, 22, 74; J.M. Li, Y. Zhang, Y. Ren, B.G. Liu, X. Lin, J. Yang, H.C. Zhao, Y.J. Wang, L. Song PLoS One 2014, 9, e106598 


\section{Figure captions}

Figure 1. General synthesis scheme of 94P200 and 94T200 copolymers

Figure 2. Molecular weight evolution during in vitro degradation (PBS, $\mathrm{pH} 7.4,37^{\circ} \mathrm{C}$ ) of $94 \mathrm{P} 200$ and 94T200 copolymers compared to PLA homopolymer (94-200)

Figure 3. Optical microscopy picture of ligament tissue engineering scaffold

Figure 4. Mechanical properties (a) typical stress-strain curves of extruded microfibers and twisted-braided scaffolds (b) evolution of the strain of a scaffold submitted to cyclic loads

Figure 5. In vitro proliferation of $\mathrm{C} 3$ cells on copolymers scaffolds. *Statistically significant difference in comparison with the TCPS control at the same time $(p<0.05)$

Figure 6. Live/Dead assay fluorescent microscopy pictures after 10 days of proliferation of C3 cells on 94P200 scaffold: staining highlights viable cells in green (A), dead cells in red (B) and copolymer autofluorescence in blue (C).

Figure 7. Cell differentiation - expression of fibroblast-related markers by C3 cells maintained in inductive culture medium on TCPS or twisted-braided scaffold versus time $(p<0.05)$

Figure 8. Cell differentiation - expression of fibroblast-related markers by $\mathrm{C} 3$ cells maintained in inductive culture medium on scaffold as a function of the mechanical stimulation versus time $(p<$ $0.05)$ 